\title{
Treating Shrunken-2 Sweet Corn Seed with Fungicide Infused via Acetone
}

\author{
Patricia E. Hung', Vincent A. Fritz ${ }^{2}$, Thor Kommedahl', \\ Albert H. Markhart, $\mathrm{III}^{4}$, and Luther Waters, $\mathrm{Jr}^{5}{ }^{5}$ \\ Department of Horticultural Science, University of Minnesota, St. Paul, \\ MN 5.5108
}

\begin{abstract}
Additional index words. supersweet, permeation, Zea mays var. rugosa, emergence, imazalil, organic solvent, Fusarium moniliforme
\end{abstract}

\begin{abstract}
Experiments were conducted to determine if the fungicide imazalil infused into shrunken-2 sweet corn (Zea mays L. var. rugosa Bonaf.) seed via acetone could protect against soil- and seedborne fungi enough to improve germination and vigor. 'Florida Staysweet' and 'Crisp-n-Sweet 710 ' seeds were infused for 0.25 hours with $1 \%$ or $2 \%(w /$ w) imazalil-acetone (LA) solutions, air-dried, and subjected to a modified laboratory seedling growth cold test using sterile soil or soil inoculated with Fusarium moniliforme Sheldon. Both IA concentrations significantly reduced the incidence of diseased seedlings in soil inoculated with $F$. moniliforme when compared to nontreated controls. Neither treatment significantly reduced the incidence of seedborne fungi. Chemical name used: 1-[2-(2,4-dichlorophenyl)-2-(2-propenyloxy)ethyl- $H$-imidazole (imazalil).
\end{abstract}

Sweet corn seeds that carry the high-sugar mutant gene shrunken-2 $\left(s h_{2}\right)$ have excellent eating and storage qualities but are susceptible to seed rot and pre- and postemergence damping off, particularly when soils are cold (10 to 15C) and wet (Styer and Cantliffe, 1984). Poor seed and seedling vigor make growers hesitant to plant $s h_{2}$ cultivars, especially when an early market product is desired. Soil- and seedborne pathogens can contribute to poor $s h$, seed and seedling vigor (Berger and Wolf, 1974; Pieczarka and Wolf, 1978). Isolations from $s h_{2}$ seed produced in Florida yielded high percentages of seed infected with Fusarium moniliforme from the field. Additionally, the deleterious effect of $F$. moniliforme infection on $s h$, seed was more noticeable during germination and emergence in cold soils (Styer and Cantliffe, 1984). Most $s h_{2}$ seed planted in the midwestem United States, however, is produced in Idaho, where $F$. moniliforme also is the primary plant pathogen associated with sweet corn (Guthrie and Anderegg, 1978), although there is no literature that documents the extent of infection in Idaho-grown $s h_{2}$ seed. How much the infected seed contributes to stand loss and reduced seedling vigor also is unknown. Recently, imazalil has shown promise in preventing potential germination

Received for publication 27 Apr. 1992. Accepted for publication 12 Nov. 1992. Minnesota Agricultural Experiment Station Journal Series. The cost of publishing this paper was defrayed in part by the payment of page charges. Under postal regulations, this paper therefore must be hereby marked advertisement solely to indicate this fact.

'Graduate Assistant.

${ }^{2}$ Associate Professor; to whom reprint requests should be addressed at the Southern Experiment Station, Waseca, MN 56093.

${ }^{3}$ Professor Emeritus, Dept. of Plant Pathology. ${ }^{4}$ Associate Professor, Dept. of Horticultural Science. ${ }^{5}$ Professor. Current address: Dept. of Horticulture, The Ohio State Univ., Columbus, OH 43210. and stand establishment problems caused by Fusarium spp. (Cornell Univ. Marketing Study, 1989).

Infusing fungicides into seed with acetone is a practical and economic alternative to aqueous treatments for controlling seed rot and pre- and postemergence damping off of soybean (Glycine max L.), cottonseed (Gossypium hirsutum L.)(O’Neilletal., 1979), and pea (Pisum sativum L.) (Papavizas et al., 1978). An infused fungicide is deposited inside and on the surface of the seed. This method improves fungicide contact with seedborne pathogens and increases protection against soilborne pathogens (Muchovej and Dhingra, 1979; Papavizas and Lewis, 1976). The fungicide is not removed easily by handling or contact with water (O'Neill et al., 1979; Papavizas and Lewis, 1976); thus, the fungicide can be used safely and it will be less likely to leach into the soil. Additionally, because the fungicide is strategically and permanently placed in the seed, less fungicide is used and its cost decreases (Persson, 1988; Shortt and Sinclair, 1980; Tao et al., 1974). There is no published information on the effect of infusing fungicides into $s h_{2}$ sweet corn seed using a solvent.

Our objectives were to a) determine the amount and kinds of seedborne fungi in $s h_{2}$ sweet corn seed produced in Idaho, b) determine if imazalil infused via acetone can eliminate $s h_{2}$ seedborne Fusarium spp., and c) sufficiently protect against soilborne $F$. moniliforme to improve germination and vigor under cold stress.

Nontreated 'Florida Staysweet' (Illinois Foundation Seed, Champaign, Ill.) and 'Crisp-n-Sweet 710' (Crookham Co., Caldwell, Idaho) $s h_{2}$ sweet corn seed was stored in a controlled-environment facility at 8 to $10 \mathrm{C}$ and $33 \%$ relative humidity (RH). Tests were conducted within 8 months of seed harvest.

One hundred seeds each of field-grown
'Florida Staysweet' and 'Crisp-n-Sweet 710' were surface-sterilized by agitation for $1 \mathrm{~min}$ in a $1.0 \%$ sodium hypochlorite solution containing $30 \mathrm{ppm}$ Tween-20. The sterilized seeds were transferred individually to vials containing sterile water and kept there for $\approx 2 \mathrm{~h}$ to soften them. The seeds were removed and halved aseptically along the embryonic axis to enhance the outgrowth of internal fungi. Five seed halves per plate were placed on acidified potato dextrose agar (APDA) and incubated for 8 days at 23 to $25 \mathrm{C}$. Fungal colonies growing from infected seed halves were counted. Initially, colonies were identified with a stereobinocular microscope $(\times 450)$, and thereafter by colony morphology. The number of fungi-infected seed is expressed on a wholeseed basis.

Field soil was obtained from a site previously planted to sweet corn and autoclaved. Half of the autoclaved soil was inoculated with $F$. moniliforme. The $F$. moniliforme inoculum was grown for 3 weeks on a mixture of $97 \%$ sand and $3 \%$ cornmeal (by weight), plus water to $25 \%$ moisture (w/v), and combined with the sterile soil in a 1 fungus<cornmealsand : 9 soil ratio. The remaining half of the soil was kept sterile. Bothmixtures were stored at 1 to $4 \mathrm{C}$ until used. Soil assays using the dilution plate method were performed periodically to ensure that the number of $F$. moniliforme colony forming units per unit of inoculated soil neither decreased nor increased, and that the sterile soil remained sterile.

The fungicide imazalil was dissolved in acetone as a $1 \%$ or $2 \%(\mathrm{w} / \mathrm{w})$ imazalil-acetone (IA) solution (Gustafson, Dallas). 'Florida Staysweet' and 'Crisp-n-Sweet 710' seed was immersed in IA solutions for $0.25 \mathrm{~h}$ and airdried overnight. Nontreated seed (NT), seed immersed in acetone only (AO) for $0.25 \mathrm{~h}$, and seed coated with a slurry of $55 \mathrm{~g}$ a.i. of $3 \alpha, 4,7,7 \alpha$-tetrahydro-2-[(trichloromethyl)thiol]-1 $H$-isoindole-1,3 (2H) -dione(captan) and $28 \mathrm{~g}$ a.i. of 4-oxathiin-3-carboxanililide (vitavax) (CV) (standard commercial treatment) per $220 \mathrm{~kg}$ of seed served as controls.

The seedling growth cold test described by the Association of Official Seed Analysts (1983) was modified to determine treatment efficacy against $F$. moniliforme under stress. A randomized complete-blockdesign was used with four replicates of 50 seeds each. Two sheets of $35.5-\times 63.0-\mathrm{cm}$ standard-weight germination towels were soaked in cold (10C) water and covered with a thin (2 to $3 \mathrm{~mm}$ ) layer of inoculated soil. Seeds were oriented with the embryo side down and the radicle pointing to the bottom of the towel to elicit a positive geotropic response on germination. A cold water mist was applied to moisten the soil and seeds. A third cold-water-soaked germination towel was placed over the seeds and soil. This procedure was repeated for all treatments using the sterile soil. The towels were rolled, placed in an upright position in a polyethylene bag, and incubated at 10C for 4 days, followed by an additional 4 days at $25 \mathrm{C}$. Following incubation and germination, the number of normal and diseased seedlings was determined according to standard procedures (Interna- 
tional Seed Testing Association, 1976). Average normal seedling dry weight-an estimate of seedling vigor-was measured by separating roots and shoots from the kernels of normal seedlings, washing off all soil, drying the seedlings at $60 \mathrm{C}$, and weighing them. Diseased seedlings also were washed to remove soil. Necrotic fragments of the diseased seedlings were removed, along with healthy tissue contiguous to the lesion, and immersed in a $1 \%$ sodium hypochlorite solution, agitated for 10 $\mathrm{sec}$, and rinsed in sterile tap water. Pieces were transferred aseptically to APDA, incubated for 8 days at 23 to $25 \mathrm{C}$, and examined for evidence of fungal infection. Colonies were counted and identified as described earlier. Data were subjected to analysis of variance and means compared using Fisher's protected LSD. Percentages were transformed using an arcsin square root transformation and analyzed. Since results were similar for both types of data, we report nontransformed data.

The incidence of seedborne Fusarium spp. fungal infection in 'Crisp-n-Sweet 710' (7\%) and 'Florida Staysweet' (8\%) was not severe. In contrast, Styer and Cantliffe (1984) reported that field-grown $\mathrm{sh}_{2}$ seed produced in Florida had severe $(>50 \%) F$. moniliforme infections for the several years it was observed. Penicillium spp. incidence was slightly lower; $2 \%$ and $4 \%$ of 'Crisp-n-Sweet 710' and 'Florida Staysweet' seed were infected, respectively. Rhizopus and Mucor spp., common surface contaminants, were recovered in only $1 \%$ of either cultivar. Aspergillus spp., a common storage fungus, occurred in $2 \%$ of 'Crisp-nSweet 710' and none of 'Florida Staysweet' seed. The low occurrence of seedborne infection indicates that it did not significantly contribute to pre- and postemergence damping off in these Idaho-produced $s h_{2}$ cultivars. The climate of southwestern Idaho is recognized as ideal for producing sweet corn seed because its long, dry growing season places minimal pathogen stress on maturing seed. Our results support that claim.

Diseased seedling incidence in NT seed in sterile soil $(8 \%)$ was about equal to the percentage of surface-sterilized seed placed on Fusarium -infected- APDA (7\%). This result suggests that diseased seedlings in sterile soil more likely are infected by seed-, not soilborne, infections. The percentages of diseased seedlings from seed treated by the other treatments (AO, 1\% IA, 2\% IA, and CV) were not significantly different from that of the NT seed '(Table 1). In sterile soil, an average of $91 \%$ of the diseased NT seedlings (of which there was $\approx 9 \%$ ) was infected by Fusarium spp. (Fig. 1a). Fusarium spp. infections appeared in all of the diseased AO seedlings; $77 \%$ and $80 \%$ of the $1 \%$ IA and $2 \%$ IA seedlings, respectively; and only $13 \%$ of the diseased CV seedlings. In 'Crisp-n-Sweet 710', the average seedling dry weight was significantly lower for both the $2 \%$ IA and the CV seedlings compared to the NT seedlings (Table 1).

In $F$. moniliforme -inoculated soil, an average of $29 \%$ of the NT seedlings showed symptoms of infection (Table 1). This result caused a significant decrease (52\%) in the average

Table 1. Percent germination and seedling condition of 'Florida Staysweet' (FS) and 'Crisp-n-Sweet 710' $(\mathrm{CnS})$ seed immersed in a $1 \%$ or $2 \%(\mathrm{w} / \mathrm{w})$ imazalil-acetone solution for $15 \mathrm{~min}$ before planting in sterile or Fusarium moniliforme-inoculated soil.

\begin{tabular}{|c|c|c|c|c|c|c|c|c|}
\hline \multirow{3}{*}{$\begin{array}{l}\text { Soil type } \\
\text { and treatment }\end{array}$} & \multicolumn{8}{|c|}{ Seedlings (\%) } \\
\hline & \multicolumn{2}{|c|}{$\begin{array}{c}\text { Germination } \\
(\%)\end{array}$} & \multicolumn{2}{|c|}{ Normal } & \multicolumn{2}{|c|}{ Diseased } & \multicolumn{2}{|c|}{$\begin{array}{c}\text { Mean seedling } \\
\text { dry wt (g) }\end{array}$} \\
\hline & FS & $\mathrm{CnS}$ & FS & $\mathrm{CnS}$ & FS & $\mathrm{CnS}$ & FS & $\mathrm{CnS}$ \\
\hline \multicolumn{9}{|l|}{ Sterile } \\
\hline $\mathrm{NT}^{\mathrm{z}}$ & $78 a^{y}$ & $83 \mathrm{a}$ & $66 a$ & $70 a$ & $8 a$ & $9 a$ & $18.0 \mathrm{a}$ & $16.8 \mathrm{a}$ \\
\hline $\mathrm{AO}$ & $87 \mathrm{a}$ & 85 a & $73 a$ & $75 a$ & $8 a$ & $7 \mathbf{a}$ & $18.8 \mathrm{a}$ & $17.8 \mathbf{a}$ \\
\hline $\mathrm{CV}$ & $79 a$ & 86 a & $68 \mathrm{a}$ & $72 \mathbf{a}$ & $5 a$ & $8 a$ & $16.0 \mathrm{a}$ & $12.0 \mathrm{c}$ \\
\hline $1 \% \mathrm{IA}$ & $86 a$ & $89 \mathrm{a}$ & $74 \mathrm{a}$ & $79 a$ & $6 a$ & $6 a$ & $16.8 \mathrm{a}$ & $16.0 \mathrm{ab}$ \\
\hline $2 \%$ IA & $80 a$ & $89 a$ & $66 a$ & $80 a$ & $5 a$ & $3 a$ & $15.0 \mathrm{a}$ & $12.8 \mathrm{bc}$ \\
\hline \multicolumn{9}{|l|}{ Inoculated } \\
\hline NT & $84 \mathrm{ab}$ & $78 \mathrm{~b}$ & $62 \mathrm{ab}$ & $41 \mathrm{~b}$ & $20 a$ & $37 \mathbf{a}$ & $18.5 \mathrm{~b}$ & $16.3 \mathbf{a}$ \\
\hline $\mathrm{AO}$ & $83 \mathrm{~b}$ & $79 \mathrm{ab}$ & $54 \mathrm{~b}$ & $47 \mathrm{~b}$ & $26 a$ & $31 \mathbf{a}$ & $19.0 \mathrm{~b}$ & $15.3 \mathrm{a}$ \\
\hline $\mathrm{CV}$ & $83 \mathrm{~b}$ & $87 \mathrm{ab}$ & $72 \mathrm{a}$ & $73 a$ & $2 \mathrm{~b}$ & $7 \mathrm{~b}$ & $17.0 \mathrm{~b}$ & $14.8 \mathrm{a}$ \\
\hline $1 \% \mathrm{IA}$ & $90 \mathrm{a}$ & $85 a b$ & $74 \mathrm{a}$ & $78 a$ & $8 \mathrm{~b}$ & $3 \mathrm{~b}$ & $21.5 \mathrm{a}$ & $19.3 \mathrm{a}$ \\
\hline $2 \% \mathrm{IA}$ & $84 \mathrm{ab}$ & $87 \mathrm{a}$ & $73 a$ & $78 \mathrm{a}$ & $3 \mathrm{~b}$ & $1 \mathrm{~b}$ & $19.3 \mathrm{ab}$ & $15.8 \mathrm{a}$ \\
\hline
\end{tabular}

${ }^{\mathrm{z}} \mathrm{NT}=$ nontreated control; $\mathrm{AO}=$ acetone-only control; $\mathrm{CV}=$ captan-vitavax control; $1 \% \mathrm{IA}=1 \%$ imazalil in acetone; $2 \% \mathrm{IA}=2 \%$ imazalil in acetone.

${ }^{y}$ Mean separation in columns within soil type by Fisher's protected LSD at $P=0.05$.

number of normal seedlings produced but not in total germination. The percent occurrence of visibly diseased seedlings produced by seed treated with $1 \%$ IA, $2 \%$ IA, or CV was reduced to $<10 \%$ (Table 1), which was about equal to the percentage of diseased seedlings that occurred in sterile soil. The percentages of normal seedlings produced by these treatments were also about equal to those occurring in sterile soil. AO was no better than NT in preventing $F$. moniliforme infection (Table 1 ). Neither seed germination percentage nor seedling average dry weight was affected by treatment.

Fusarium moniliforme was recovered from all diseased seedlings growing in inoculated soil from all treatments (Fig. lb) except CV. Only $31 \%$ of the CV diseased seedlings seemed to have been infected by $F$. moniliforme. Another $6 \%$ was infected by Penicillium spp. The remaining $\mathrm{CV}$ diseased seedlings were free from fungal growth.

In soil inoculated with $F$. moniliforme, NT

STERILE SOIL
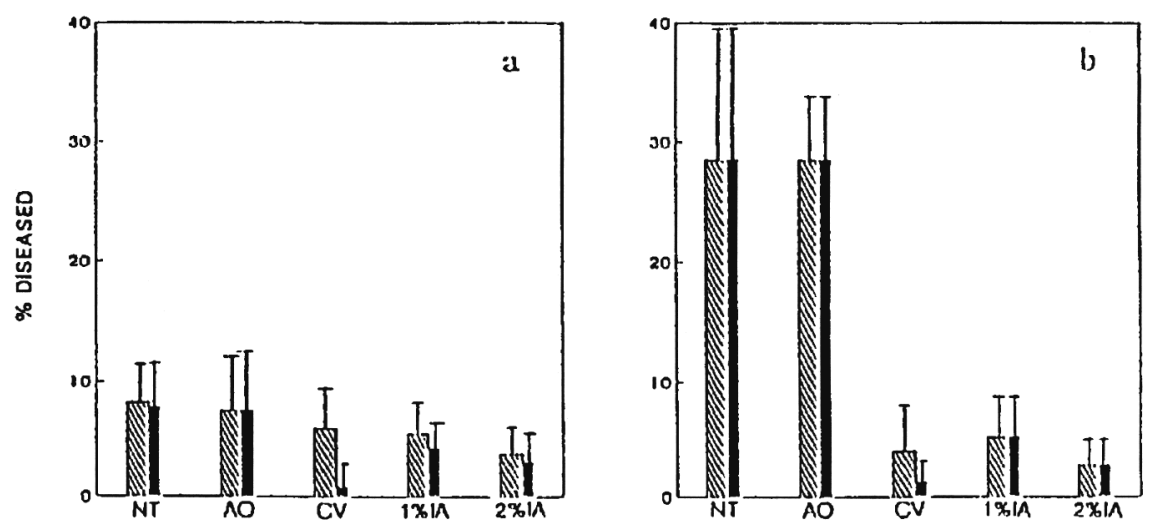

'Crisp-n-Sweet 710' seed produced almost twice the number of diseased seedlings $(37 \%)$ as did NT 'Florida Staysweet' seed (20\%), although the total number of germinated seed was about equal (Table 1). In contrast, disease occurrence in seedlings grown in sterile soil was low for both cultivars and about equal to each other (7\%, 'Crisp-n-Sweet 710'; 8\%, 'Florida Staysweet'). Both cultivars responded equally well to all protective treatments (Table 1). Seedborne fungi did not contribute significantly to pre- and postemergence damping off.

IA at $1 \%$ and $2 \%$ was as effective in preventing infection by soilborne $F$. moniliforme in these $s h$,cultivars as CV (Table 1). In sterile soil, however, seedling vigor, as exhibited by dry weight, of $2 \%$ IA-infused seed seemed to suffer. None of the treatments seemed to control seedborne $F$. moniliforme infections effectively. Although the actual degree of imazalil penetration was not ascertained, the 15-min immersion of the seed in IA may have been only long enough for imazalil to pen-

INOCULATEO SOIL

त्राण DISEASED SEEDLINGS DISEASED SEEDLINGS WITII FUSARIUM SRP. INFECTIONS

Fig. 1. Incidence of diseased seedlings and percentage of Fusarium-infected shrunken-2 sweet corn seedlings germinated in (a) sterilized and (b) inoculated soil. Vertical lines indicate the SE of the mean of four replicates. $\mathrm{NT}=$ nontreated control, $\mathrm{AO}=$ acetone-only control, $\mathrm{CV}=$ captan-vitavax control, $1 \% \mathrm{IA}$ $=1 \%$ imazalil in acetone, and $2 \% \mathrm{IA}=2 \%$ imazalil in acetone. 
etrate through the pericarp and no further, thereby making these treatments partially or wholly ineffective against deep-seated $F$. moniliforme infections. O'Neill et al. (1979) reported that 5-ethoxy-3-(trichloromethyl)1,2,4-thiadiazole (ethazol) applied in acetone to soybean seed reached a maximum concentration under the seedcoat in $\approx 15 \mathrm{~min}$, and that little further penetration occurred with longer immersion times. Since infusing fungicide into sweet corn seed was not studied, a 15-min immersion time seemed logical. Other reports (Lewis et al., 1979; Tao and Khan, 1974), however, indicate that the quantity of chemical penetrating the seed and the depth of its penetration depended on the chemical used, seed type, permeation time, and solution concentration. Simply increasing the immersion time for these $s h$, cultivars might result in deeper, more effective imazalil penetration and make the fungicide more effective against seedbome $F$. moniliforme.

IA at $1 \%$ was as effective as $2 \%$ IA. The cost-effectiveness of using $1 \%$ IA vs. CV, however, was not assessed. The method we used to infuse the fungicide into the seed would not be economically sound in a commercial operation. Once one batch of seed was treated, the solution was disposed of, and no attempt was made to determine how much imazalil actually penetrated the seed. However, Papavizas et al. (1978) reported that $N$ (2,6-dimethylphenyl)- $N$-(methoxyacetyl)- DLalanine methyl ester (metaxanin)-acetone solution, in which 30 batches of seed had been immersed previously, effectively protected pea seed against Pythium ultimum. Also, industrial processes that were not available for use in our laboratory experiments can recycle almost all of the solvent used as it evaporates and as it is wasted. These processes are more economically and environmentally attractive.

Fusarium moniliforme did not significantly affect germination but significantly decreased the number of normal seedlings. This result suggests that, although $F$. moniliforme may not affect germination directly, it affects seedling growth. Infected plants may emerge slowly, if at all. And, even if they do emerge, they most likely would be more susceptible to damping off and other postemergence problems. Additionally, in naturally infested soils, $F$. moniliforme invasion could make weakened seed more vulnerable to attack by other pathogens before, during, or after germination.

We recognize that susceptibility to $F$. moniliforme attack is only one of many factors contributing to poor $s h_{2}$ seed and seedling vigor. Using acetone to infuse imazalil is a viable alternative to $\mathrm{CV}$ to protect $s h_{2}$ seed from fungal invasion. With additional research, infusing fungicides with organic solvents may be superior.

\section{Literature Cited}

Association of Official Seed Analysts. 1983. Seed vigor testing handbook. Contrib. 32.

Berger, R.D. and E.A. Wolf. 1974. Control of seedborne and soilborne mycoses of 'Florida Staysweet' corn by seed treatment. Plant Dis. Rptr. 58:922-923.

Cornell Univ. Marketing Study. 1989. Sweet corn production. The Great Lakes Veg. Growers Nwsl. March:13.

Guthrie, J.W. and J. Anderegg. 1978. Fungi isolated from seed of Idaho sweet corn, Zea mays var. saccharata. Phytopathol. Nwsl. 12: 179. (Abstr.) International Seed Testing Association. 1976. The germination test. Seed Sci. \& Technol. 4:23-28. Lewis, J.A., G.C. Papavizas, and N.R. O'Neill. 1979. Effect of seed immersion in organic solvents on germinability. J. Agr. Sci. (Camb.) 92:563-570.

Muchovej, J.J. and O.D. Dhingra. 1979. Benzene and ethanol for treatment of soybean seeds with systemic fungicides. Seed Sci. Technol. 7:449454.

O'Neill, N.R., G.C. Papavizas, and J.A. Lewis. 1979. Infusion and translocation of systemic fungicides applied to seeds in acetone. Phytopathology 69:690-694.

Papavizas, G.C. and J.A. Lewis. 1976. Acetone infusion of pyroxychlor into soybean seed for the control of Phytophthora megasperma var. sojae. Plant Dis. Rptr. 60:484-488.

Papavizas, G.C.. J.A. Lewis, J.C. Locke. and N.R. O'Neill. 1978. Organic solvent infusion technique for fungicide application to seeds. Phytopathol. Nwsl. 12:179. (Abstr.)

Persson, B. 1988. Enhancement of seed germination by plant growth regulators infused via acetone. Seed Sci. Technol. 16:391-404.

Pieczarka, D.J. and E.A. Wolf. 1978. Increased stand of 'Florida Staysweet' corn by seed treatment with fungicides. Proc. Florida State Hort. Soc. 91:290-291.

Shortt, B.J. and J.B. Sinclair. 1980. Efficacy of polyethyleneglycol and organic solvents for infusing fungicides into soybean seed. Phytopathology 70:971-973.

Styer, R.C. and D.J. Cantliffe. 1984. Infection of two endosperm mutants of sweet corn by Fusurium moniliforme and its effect on seedling vigor. Phytopathology 74:189-194.

Tao, K. and A.A. Khan. 1974. Penetration of dry seeds with chemicals applied in acetone. Plant Physiol. 54:956-958.

Tao, K.L., A.A. Khan, G.E. Harman, and C.J. Eckenrode. 1974. Practical significance of the application of chemicals in organic solvents to dry seeds. J. Amer. Soc. Hort. Sci. 99:217-220. 